\title{
THE ROLE OF POLITICAL STABILITY IN FOREIGN DIRECT INVESTMENT ATTRACTION: CROSS-COUNTRY ANALYSIS \\ Rogneda Groznykh ${ }^{1}$, Oleg Mariev ${ }^{2,3}$, Sergey Plotnikov $^{4}$, Maria Fominykh ${ }^{5}$
}

\begin{abstract}
This study is devoted to the evaluation and scrutiny of political stability as a determinant of foreign direct investment (FDI) inflows to different countries. The primary objective of the research is to estimate the impact and influence of various indicators of political stability on foreign direct investment inflows. The analysis is delivered based on a database on cross-country FDI inflows of 66 FDI-importer countries and 98 FDI-exporter countries, in the period between 2001-2018. This article uses the assumption that the impact of political stability might be different for both the groups of developed and developing countries. As the developed economies have higher political stability, they tend to attract larger amounts of foreign direct investment compared to developing economies, where the political situation can be less stable. Furthermore, the estimation applies the gravity approach, while the main method used for the econometric calculations is the Pseudo Poisson Maximum Likelihood (PPML) regression. The outcome revealed that in most cases the indicators of political stability had a positive impact on the foreign direct investment inflows. However, the results are not constant for all groups of countries. Therefore, if a developed country is an importer of investment, then most of the indicators of political stability become significant and have a positive influence on the foreign direct investment. At the same time, if the importer is a developing country, then for the investor-developed economy, political stability becomes a significant factor. Similarly, if the FDI-exporter is a developing economy, then determinants of political stability are insignificant. Based on these results, possible recommendations for refined government policies can be suggested.
\end{abstract}

JEL Classification Numbers: F21, DOI: https://doi.org/10.12955/peb.v1.22

Keywords: Foreign Direct Investment, Institutional Environment, Gravity Model, Government Stability, Internal and External Conflicts, Democracy

\section{Introduction}

Nowadays, foreign direct investment has become one of the main factors stimulating economic development for different countries, by virtue of an increase in technological exchanges and in the efficiency of households. In addition, FDI lead to an improvement in the potential to cover the financial exigency of government by financial inflows and provisions for employment. Many determinants of foreign direct investment are also currently being studied, in conformity to the article. Institutional environment is thus, one of the key factors that influence volumes of foreign direct investment inflows, including political risks and political stability of a country in particular. This can further be demonstrated when political stability in a country is higher, this leads to a fall in the risks for investors. Political risks can cause a negative impact on the attraction of foreign direct investment, because they affect the business environment between the countries, make the investors vulnerable and increase the expenses of conducting business.

As regards the developed countries, they are usually associated with lower political risk. Moreover, despite high rates of the economic growth in developing countries, a majority of them still lag behind the countries of Western Europe and USA. This happens as a result of the existence of military conflicts in the developing countries, inefficiency of government management and political institutions in entirety. The analysis of political stability indicators for developed and developing economies allows us an opportunity to compare countries and work out solutions to increase political stability, which in turn would give a boost to foreign direct investment inflows into the host economy.

Therefore, the main aim of the study presented is to discover and calculate the effects of political stability on foreign direct investment inflows. It is important to note that political environment comprises of various factors, which have also been included into the analysis as independent variables. Furthermore, we evaluated this effect separately for developed and developing countries in order to

\footnotetext{
${ }^{1}$ Ural Federal University, Graduate School of Economics and Management, Department of Econometrics and Statistics, Yekaterinburg, Russian Federation, roneda.groznykh@urfu.ru

${ }^{2}$ Graduate School of Economics and Management, Ural Federal University, Yekaterinburg, Russian Federation, o.s.mariev@urfu.ru

${ }^{3}$ Institute of Economics, The Ural Branch of the Russian Academy of Sciences, Yekaterinburg, Russian Federation,o.s.mariev@urfu.ru

${ }^{4}$ Ural Federal University, Graduate School of Economics and Management, Department of Econometrics and Statistics, Yekaterinburg, Russian Federation, serge.plotnikov@ gmail.com

${ }^{5}$ Ural Federal University, Graduate School of Economics and Management, Department of Econometrics and Statistics, Yekaterinburg, Russian Federation, maria.fominykh@gmail.com
} 
compare the relevance of institutional factors on FDI inflows and to define which economies were more successful in FDI attraction. For the purpose in concern, 12 different indicators of political stability were used in the econometric estimation. The indices were calculated by the PRS-Group (2018). Taking into account the methodology used by the PRS-Group, an indicator of political risk was assessed along with its impact on FDI. An econometric model was constructed based on the gravity approach, in which the dependent variables were bilateral FDI inflows. The estimation was conducted using the Pseudo Poisson Maximum Likelihood method. The analysis was then carried out separately for four country groups: when both FDI-importer and FDI-exporter are developed economies, developed FDI-importer with developing FDI-exporter economy, developing FDIimporter with developed FDI-exporter country and when both are developing countries.

\section{Literature Review}

At present, a wide range of studies committed to the investigation of the determinants of foreign direct investment exist, but the institutional factors, that comprehend the impact of political stability on foreign direct investment inflows, still stir intrigue in researchers. Some studies provide an empirical analysis of the influence of economic, financial and institutional factors on foreign direct investment inflows.

Since the end of the twentieth century, many economists have attempted to explore the factors that determine the inflows of FDI to different countries. For example, Fry et al. (1995) arrived at the conclusion that export-oriented countries and exchange rate remarkably influenced FDI inflows. Hence, the amount of FDI coming into the host-economy directly depended on these factors. Another article on determinants of foreign direct investment, declared that the most significant factors that directed foreign direct investment inflows to countries with consistently high FDI indicators were the political risk and the business environment of the recipient country. For the countries that accepted relatively less investment, the main determinant of foreign direct investment was the socio-economic condition. Additionally, countries that were focused on increasing the volume of export also attracted more foreign direct investment into their economy (Singh et al., 1995).

It should also be considered that in earlier researches the institutional indicators, including political stability indicators, were measured by different quantitative variables, such as: the number of revolutions in the country, the incidence of crimes per 1000 people, the amount of accepted and rejected reforms, the distribution of private property, the number of armed conflicts, etc. (Brunetti and Weder, 1998; Bevan et al., 2004). Such measures usually restrict the study of greater samples of countries and time periods, owing to the lack of statistical data. As an alternative measure, proxyvariables and indices were used for institutions. Some researchers juxtapose the quantitative indicators and proxy-variables and generally reckon that proxies prove to be more efficient and elucidative measures than quantitative ones (Knack and Keefer, 1995).

Modern day research economists tend to use proxy-variables as institutional indicators. Madr and Kouba (2015) also applied proxy-variables in their research, which were considered by the World Bank as institutional variables. They also utilized the Herfindahl-Hirschman index for the states. As their research, the authors concluded that political stability indicators had a significant impact on foreign direct investment for the developing countries. A greater spectrum of institutional indicators was discussed in a number of other studies, which confirm that corruption, political stability and the level of democracy and freedom significantly affected foreign direct investment inflows (Tintin, 2013; Daude, 2007; Benassy-Quere et al., 2007).

Later studies also considered the implications of political risks and political stability on FDI inflows. For example, Bitar et al. (2019) conducted a research on the impact of such factors for attracting FDI in the Lebanese economy. The authors then confirmed that political risk significantly affected foreign direct investment.

\section{Methodology}

The principal research approach put forward in this article is the 'gravity model'. The authors have already applied it for the purpose of scrutinizing the effect of various factors on FDI attraction in their previous studies (Mariev O., 2016; Groznykh R., 2019). Empirical analyses illustrate that this research method was one of the most efficient in estimating the influence of factors on bilateral FDI flows, due to its provision of accuracy in results. 
The approach considered distance between the investor-country and the importer-country for foreign direct investment along with the market size of the economies of the countries, so the basic equation for the gravity model can be represented as follows:

$$
F D I_{i j t}=\frac{G D P_{i} G D P_{j}}{\text { Dist }_{i j}}
$$

where $F D I_{i j t}$ represents flow of foreign direct investment from country $\mathrm{i}$ to country $\mathrm{j}$ in the time $\mathrm{t}$, $G D P_{i}$ and $G D P_{j}$ are gross domestic products of the investor-country and the FDI-recipient country, which indicate the size of the economies, and $D i s t_{i j}$ refers to the distance between the countries.

The gravity model suggested two main assumptions, which were also elaborated in the previous research: the first assumption intended to explain that with an increase in the size of the economies (gross domestic product) the volume of foreign direct investment flows between the countries would also increase. The second assumption proposed that with an increase in the distance between countries, the foreign direct investment flows would decrease. In other words, countries that are neighbors tend to exchange greater volumes of foreign direct investment than countries which are located farther away.

The main econometric method used for estimation is the Pseudo Poisson Maximum Likelihood method, which considered a non-linear form of the gravity model:

$$
y_{i}=\exp \left(x_{i} \beta\right)+\varepsilon_{i}
$$

, and was first proposed by Silva and Tenreyro for the estimation of the gravity model (Silva S., 2006). As soon as the data used for the estimation becomes heteroscedastic, this method decreases the effect of the heteroscedasticity and biasness of regression results.

\section{Data}

The research was delivered on based on the dataset on annual bilateral foreign direct investment flows of 66 FDI-recipient countries and 98 FDI-investor countries. This dataset covers the period from 2001 to 2018. It is important to be conscious of certain countries as they can cause biasness in the estimations, for example, offshore countries, which were excluded from the database. As regards the level of development, the dataset comprised of 33 developed economies and 33 developing countries as the importers of FDI.

The initial equation for the econometric estimation is displayed as follows:

$$
\begin{gathered}
\text { FDI }_{i j t}=\exp \left(\beta_{1} \operatorname{lngdpIMP}_{\mathrm{it}}+\beta_{2} \operatorname{lngdpEXP}_{\mathrm{it}}+\beta_{3} \text { Indist }_{\mathrm{ij}}+\beta_{4} \text { Openness }_{\mathrm{it}}+\right. \\
\left.+\beta_{5} \text { Inf }_{\mathrm{it}}+\beta_{6} \text { PolStab }_{\mathrm{it}}\right)+\varepsilon_{\mathrm{ij}}
\end{gathered}
$$

\begin{tabular}{|c|c|c|}
\hline $\begin{array}{l}\text { Variable } \\
\text { Label }\end{array}$ & Variable Description & Source \\
\hline FDI & $\begin{array}{l}\text { Foreign direct investment inflow from } \\
\text { country } \mathrm{j} \text { to country } \mathrm{i} \text { in the period } \mathrm{t}\end{array}$ & $\begin{array}{l}\text { Coordinated Direct Investment Survey } \\
\text { provided by the International Monetary Fund }\end{array}$ \\
\hline lngdpIMP & $\begin{array}{l}\text { Logarithm of gross domestic product of } \\
\text { country FDI-recipient }\end{array}$ & \multirow[t]{2}{*}{ World Bank database } \\
\hline lngdpEXP & $\begin{array}{l}\text { Logarithm of gross domestic product of } \\
\text { country-investor }\end{array}$ & \\
\hline lnDist & $\begin{array}{l}\text { Logarithm of distance between capitals of } \\
\text { country pairs }\end{array}$ & Mayer and Zignago, 2011 \\
\hline Openness & Trade (percent of GDP) & \multirow[t]{3}{*}{ World Bank database } \\
\hline Inf & Inflation (\%) & \\
\hline $\operatorname{lnExch}$ & $\begin{array}{l}\text { Logarithm of exchange rate (local } \\
\text { currency to dollar) }\end{array}$ & \\
\hline PolStab & Vector of political stability variables & PRS-Group \\
\hline
\end{tabular}

The description of the data is presented in table 1.

The vector of the institutional variables consisted of twelve indices for political stability estimated by the PRS-Group. The "Government stability" index shows the performance of the government, its 
ability to carry out announced plans or schemes and national projects. "Socio-economic conditions" relates to the social and economic environment provided by the government for the public. It also refers to socio-economic constraints that people encounter at work or in life, which can aggravate into worker strikes or other civil conflicts. "Investment profile" indicates the risk to invest. This indicator considers contract viability, the mechanism of profit repatriation, delays in payment, etc. "Internal conflict" and "External conflict" implies war (or civil war), inner or cross-border disputes, foreign pressures, etc. "Corruption" points to the assessment of corruption in the political sphere. Corruption in politics is often associated with low government efficiency, high expenses for investors and, therefore, diminished inflows of foreign direct investment. In this research, we consider corruption as the main factor influencing foreign direct investment in developing countries. "Military in politics", "Religious Tensions" and "Ethnic Tensions" show how governments regulate apprehensions expressed by different people, internal as well as external conflicts, and how population is tolerant to various social groups. "Law and order" refers to the combination of civil and religious laws and regulations and how people follow them. The last two indicators, "Democratic Accountability" and "Regulation quality", indicate the accountability of the government to its citizens and the volume of revisions that occur when a government changes (The PRS Group, 2018). As these indices inversely relate to the level of risk, the higher the indices are, the lower the political risk is.

It must be considered that all the indices employed in the research are strongly correlated. In order to deal with the multicollinearity problem, all these indicators were integrated into four groups (Bitar, 2019), which are depicted in table 2.

\begin{tabular}{|l|l|l|l|}
\hline \multicolumn{2}{|l|}{ Table 2: Integrated groups of political stability indicators } \\
\hline Corruption in Politics & Government Management & Inclusion & External Policy \\
\hline \multirow{4}{*}{ Corruption } & Government Stability & Socio-Economic Conditions & External Conflict \\
\cline { 2 - 3 } & Regulation Quality & Ethnic Tensions & Investment Profile \\
\cline { 2 - 3 } & Democratic Accountability & Internal Conflict & \\
\cline { 2 - 3 } & Military in Politics & Religious Tensions & \\
\cline { 2 - 3 } & Law and Order & & \\
\hline
\end{tabular}

Source: Authors

Bearing the data and research results of previous studies in mind, the central hypothesis states that political risk indices have positive and significant impact on foreign direct investment, such that with an increase in the value of an index, the amount of foreign direct investment would increase.

The second hypothesis that was tested is that not all indices are relevant for different groups of countries. We divide our database into 4 groups: i) developed FDI-importers and developed FDIexporters, ii) developed FDI-importers and developing FDI-exporters, iii) developing FDI-exporters and developed FDI-importers, and iv) both, developing exporters and importers of FDI.

\section{Results and Discussion}

As mentioned above, the main econometric method used is the Pseudo Poisson Maximum Likelihood (PPML) regression. This method is deemed to be one of the most effective methods for gravity model estimation as it gives more accurate and unbiased results. The only limitation of the method is that it does not incorporate negative observations. However, as negative observations always exist for each country pairs (investor and importer), less than $10 \%$ of the sample was not included in the analysis.

While the political indicators strongly correlate/ have strong correlation with each other, five specifications of the model were stipulated. Therefore, for each pair of countries five regressions were run with the indices: corruption, government management, inclusion, external policy and political risk, which covered all the aforesaid indicators and which were calculated by the PRS-Group. The maximum value of the index is 100 , so if the political risk index is lower than 49 , it reads as very high risk. If the value lies between 80 and 100, it indicates very low risk. The results for the first group, developed FDI-importer and developed FDI-exporter, are represented in table 3.

As per the results, when both the investor country and the host country are developed economies, then 'control of corruption' is one of the most significant factors. A one-point increase in the corruption index causes a 0.8172-million-dollar increase on average, in the volume of foreign direct investment. Similarly, the 'inclusion' factor, which includes socio-economic conditions and internal conflicts and 
tensions is prominent at the level of 5\%, and with an increase in it by one point, the volume of foreign direct investment increases by 0.1245 million dollars on average. The general risk index is of a relatively lesser importance than other factors, nonetheless, if it increases by one point, FDI inflows rise by 0.105 million dollars. Government management and External Policy factors seem to be insignificant for the selected group of countries. This can be interpreted in the sense that most of the countries included in this group are countries of the European Union and USA. Moreover, countries with higher political stability indicators such as Germany, Netherlands, and France tend to attract more FDI than Croatia or Hungary, which further confirms the results.

\begin{tabular}{|c|c|c|c|c|c|}
\hline FDI & Corruption & $\begin{array}{l}\text { Government } \\
\text { Management }\end{array}$ & Inclusion & External Policy & Political Risk \\
\hline \multirow{2}{*}{$\begin{array}{l}\text { Logarithm of } \\
\text { GRP importer }\end{array}$} & $0.8172 * * *$ & $0.8369 * * *$ & $0.8227 * * *$ & $0.8326 * * *$ & 0.8251 *** \\
\hline & $(19.72)$ & (19.57) & (20.41) & (20.84) & (20.02) \\
\hline \multirow{2}{*}{$\begin{array}{l}\text { Logarithm of } \\
\text { GRP exporter }\end{array}$} & $0.5703 * * *$ & $0.5716^{* * *}$ & $0.5734 * * *$ & $0.5715 * * *$ & $0.5727 * * *$ \\
\hline & (18.60) & (18.53) & (18.69) & (18.58) & (18.66) \\
\hline \multirow{2}{*}{$\begin{array}{l}\text { Logarithm of } \\
\text { distance }\end{array}$} & $-0.5347 * * *$ & $-0.5421 * * *$ & $-0.5479 * * *$ & $-0.5435 * * *$ & $-0.5434 * * *$ \\
\hline & $(-14.59)$ & $(-14.65)$ & $(-14.92)$ & $(-14.80)$ & $(-14.78)$ \\
\hline \multirow{2}{*}{ Inflation } & $-0.1044 * * *$ & $-0.1076 * * *$ & $-0.1069 * * *$ & $-0.1084 * * *$ & $-0.1075 * * *$ \\
\hline & $(-4.35)$ & $(-4.66)$ & $(-4.62)$ & $(-4.68)$ & $(-4.62)$ \\
\hline \multirow{2}{*}{$\begin{array}{l}\text { Logarithm of } \\
\text { exchange rate }\end{array}$} & $-0.0519 *$ & $-0.0560 * *$ & $-0.0662 * *$ & $-0.0559 * *$ & $-0.0578 * *$ \\
\hline & $(-1.81)$ & $(-2.00)$ & $(-2.30)$ & $(-1.98)$ & $(-2.04)$ \\
\hline \multirow{2}{*}{ Openness } & $0.0125 * * *$ & $0.0128 * * *$ & $0.0126^{* * *}$ & $0.0127 * * *$ & $0.0125 * * *$ \\
\hline & $(6.27)$ & $(6.39)$ & $(6.43)$ & $(6.65)$ & $(6.39)$ \\
\hline \multirow{2}{*}{ Political Indicator } & $0.1015 * * *$ & 0.0114 & $0.1245^{* *}$ & 0.0429 & $0.0105^{*}$ \\
\hline & $(2.90)$ & $(0.14)$ & $(2.15)$ & $(1.07)$ & $(1.74)$ \\
\hline \multirow{2}{*}{ Constant } & $-8.4818 * * *$ & $-8.3809 * * *$ & $-8.9524 * * *$ & $-8.6801 * * *$ & $-8.9826 * * *$ \\
\hline & $(-12.03)$ & $(-11.21)$ & $(-11.03)$ & $(-10.36)$ & $(-10.78)$ \\
\hline $\mathrm{r} 2$ & 0.1814 & 0.1822 & 0.1835 & 0.1824 & 0.1819 \\
\hline $\mathrm{N}$ & 14742 & 14742 & 14742 & 14742 & 14742 \\
\hline
\end{tabular}

Note: Robust standard errors are in the parenthesis. $* * *$ indicates $1 \%$ significance level, $* *$ indicates $5 \%$ significance level and * indicates $10 \%$ significance level.

Source: Authors

Table 4. Regression results for developed FDI-importer and developing FDI-exporter

\begin{tabular}{|c|c|c|c|c|c|}
\hline & Corruption & $\begin{array}{l}\text { Government } \\
\text { Management }\end{array}$ & Inclusion & External Policy & Political Risk \\
\hline \multirow{2}{*}{$\begin{array}{l}\text { Logarithm of } \\
\text { GRP importer }\end{array}$} & $0.6359 * * *$ & $0.6300 * * *$ & $0.6351 * * *$ & $0.6686^{* * * *}$ & $0.6284 * * *$ \\
\hline & $(13.55)$ & $(12.70)$ & $(13.19)$ & $(13.73)$ & $(12.98)$ \\
\hline \multirow{2}{*}{$\begin{array}{l}\text { Logarithm of } \\
\text { GRP exporter }\end{array}$} & $0.5577 * * *$ & 0.5828 *** & $0.5647 * * *$ & $0.5572 * * *$ & $0.5701 * * *$ \\
\hline & $(11.61)$ & $(12.28)$ & $(11.89)$ & $(11.59)$ & $(11.96)$ \\
\hline \multirow{2}{*}{$\begin{array}{l}\text { Logarithm of } \\
\text { distance }\end{array}$} & $-0.6056 * * *$ & $-0.6238 * * *$ & $-0.6016^{* * *}$ & $-0.5818 * * *$ & $-0.6118 * * *$ \\
\hline & $(-5.74)$ & $(-5.98)$ & $(-5.81)$ & $(-5.52)$ & $(-5.88)$ \\
\hline \multirow{2}{*}{ Inflation } & $0.0082 * * *$ & $0.0074 * * *$ & $0.0082 * * *$ & 0.0087 *** & $0.0077 * * *$ \\
\hline & $(4.04)$ & $(3.76)$ & $(4.30)$ & (4.53) & $(3.97)$ \\
\hline \multirow{2}{*}{$\begin{array}{l}\text { Logarithm of } \\
\text { exchange rate }\end{array}$} & $0.0584 *$ & 0.0496 & 0.0460 & 0.0427 & 0.0492 \\
\hline & $(1.88)$ & $(1.34)$ & $(1.29)$ & $(1.25)$ & $(1.35)$ \\
\hline \multirow[b]{2}{*}{ Openness } & $-0.1900 * * *$ & $-0.1804 * * *$ & $-0.2204 * * *$ & $-0.1979 * * *$ & $-0.2040 * * *$ \\
\hline & $(-3.99)$ & $(-3.93)$ & $(-4.65)$ & $(-4.30)$ & $(-4.35)$ \\
\hline \multirow{2}{*}{ Political Indicator } & $0.2003 * * *$ & 0.6876 *** & 0.2736 ** & 0.0125 & 0.0368 *** \\
\hline & (3.10) & $(4.08)$ & $(2.02)$ & $(0.35)$ & $(3.07)$ \\
\hline \multirow{2}{*}{ Constant } & $-7.1742 * * *$ & $-10.1981 * * *$ & $-8.3544 * * *$ & $-7.2692 * * *$ & $-9.2757 * * *$ \\
\hline & $(-6.03)$ & $(-7.37)$ & $(-5.99)$ & $(-6.19)$ & $(-6.74)$ \\
\hline $\mathrm{r} 2$ & 0.0240 & 0.0259 & 0.0238 & 0.0231 & 0.0246 \\
\hline $\mathrm{N}$ & 33030 & 33030 & 33030 & 33030 & 33030 \\
\hline
\end{tabular}

Note: Robust standard errors are in the parenthesis. $* * *$ indicates $1 \%$ significance level, $* *$ indicates $5 \%$ significance level and $*$ indicates $10 \%$ significance level.

Source: Authors 
In table 4 the results the second group, developed FDI-importer and developing FDI-exporter, are represented.

According to the results in table 4, developed economies tend to attract more foreign direct investment. For the investors from developing country, indicators such as corruption, government management and inclusion are significant. The "political risk" indicator is significant at the level of $1 \%$, so the lower the risk, and the more foreign direct investment flow into the economy. If the 'control for corruption' indicator increases by one point, then FDI inflow increases by 0.2 million dollars on average. The 'Government management' indicator includes the ability of regulation, democratic accountability, military in politics and law and order. Developed countries usually associated themselves with higher values of such indicators. Therefore, the more democratic the country is, the less military it will use in politics, and the better the regulation and the legal systems will be, attracting more foreign direct investment into the country.

Consequently, tables 3 and 4 confirm the first hypothesis that an increase in political stability promotes an increase in the foreign direct investment inflows. External policy turned out to be rather insignificant for the developed FDI-importer. The results for the third group, developing FDI-importer and developed FDI-exporter, are represented in table 5, and that of the fourth group, developing FDIimporter and developing FDI-exporter, are represented in table 6.

\begin{tabular}{|c|c|c|c|c|c|}
\hline & Corruption & $\begin{array}{l}\text { Government } \\
\text { Management }\end{array}$ & Inclusion & External Policy & Political Risk \\
\hline \multirow{2}{*}{$\begin{array}{l}\text { Logarithm of } \\
\text { GRP importer }\end{array}$} & $0.5918 * * *$ & $0.5865^{* * *}$ & $0.5679 * * *$ & $0.6173 * * *$ & $0.5789 * * *$ \\
\hline & (30.04) & $(28.11)$ & $(26.13)$ & $(29.89)$ & $(27.33)$ \\
\hline \multirow{2}{*}{$\begin{array}{l}\text { Logarithm of } \\
\text { GRP exporter }\end{array}$} & $0.6135^{* * *}$ & $0.6106^{* * *}$ & $0.6121 * * *$ & $0.6159 * * *$ & $0.6142 * * *$ \\
\hline & $(21.31)$ & $(21.06)$ & $(21.54)$ & (22.04) & $(21.56)$ \\
\hline \multirow{2}{*}{$\begin{array}{l}\text { Logarithm of } \\
\text { distance }\end{array}$} & $-0.3005 * * *$ & -0.2486 *** & $-0.2678 * * *$ & $-0.3190 * * *$ & $-0.2800 * * *$ \\
\hline & $(-3.43)$ & $(-3.03)$ & $(-3.38)$ & $(-3.91)$ & $(-3.40)$ \\
\hline \multirow{2}{*}{ Inflation } & $-0.0090 * * *$ & $-0.0086 * * *$ & $-0.0121 * * *$ & $-0.0120 * * *$ & $-0.0119 * * *$ \\
\hline & $(-3.44)$ & $(-3.09)$ & $(-3.56)$ & $(-4.04)$ & $(-3.32)$ \\
\hline \multirow{2}{*}{$\begin{array}{l}\text { Logarithm of } \\
\text { exchange rate }\end{array}$} & $-0.0514 * * *$ & $-0.0564 * * *$ & $-0.0443 * * *$ & $-0.0525 * * *$ & $-0.0481 * * *$ \\
\hline & $(-5.28)$ & $(-5.79)$ & $(-4.42)$ & $(-5.25)$ & $(-4.84)$ \\
\hline \multirow{2}{*}{ Openness } & 0.0045 & 0.0220 & 0.0356 & 0.0193 & 0.0250 \\
\hline & $(0.16)$ & $(0.83)$ & $(1.39)$ & $(0.76)$ & $(0.99)$ \\
\hline \multirow{2}{*}{$\begin{array}{l}\text { Political } \\
\text { Indicator }\end{array}$} & $0.2461 * *$ & -0.0686 & $0.1499 * *$ & $0.1303 * * *$ & $0.0224 * *$ \\
\hline & $(2.30)$ & $(-0.62)$ & $(2.57)$ & $(5.92)$ & $(2.32)$ \\
\hline \multirow{2}{*}{ Constant } & $-7.2557 * * *$ & $-6.8038 * * *$ & $-7.4528 * * *$ & $-9.0675 * * *$ & $-8.0482 * * *$ \\
\hline & $(-9.74)$ & $(-9.59)$ & $(-10.04)$ & $(-11.83)$ & $(-11.12)$ \\
\hline $\mathrm{r} 2$ & 0.1248 & 0.1161 & 0.1224 & 0.1285 & 0.1251 \\
\hline $\mathrm{N}$ & 18524 & 18524 & 18524 & 18524 & 18524 \\
\hline
\end{tabular}

Note: Robust standard errors are in the parenthesis. $* * *$ indicates $1 \%$ significance level, $* *$ indicates $5 \%$ significance level and $*$ indicates $10 \%$ significance level.

Source: Authors

As displayed in table 5, if the investor is a developed country and the host economy is a developing one, then indicators such as control for corruption, inclusion and external policy are significant. The most significant factor is external policy. With the increase in these indices by one point, the amount of foreign direct investment increases by 0.13 million dollars. If there is a one-point increase in the 'control for corruption' factor in developing countries, then the foreign direct investment inflows increase by 0.246 million dollars. It is worth noting that if the same indicator increases for the developed countries, it leads to a comparatively lesser increase in FDI (by 0.1015 and 0.2 million dollars), which implies that corruption control is more important for the developing economies and the effect of its progression will be more remarkable. As regards developing economies, an indicator such as inclusion also becomes significant in order to attract FDI. Improvement of socio-economic conditions and a decrease in internal conflicts and tensions between social groups will increase FDI inflows by 0.15 million dollars on average. With an increase in the external policy indicator, FDI increases by 0.1303 million dollars on average. The general political risk index is also important, 
which indicates that improvement in political stability leads to increase in foreign direct investment by 0.022 million dollars.

Table 6 shows the specific results of practical calculations. Accordingly, almost all indicators of political stability are insignificant, except government management. A possible explanation for this is that there exist more substantial factors for the foreign direct investment inflows between developing economies, such as amount of export and import, common border, common language or religion. An improvement in government management might lead to decrease in FDI between developing countries, owing to more complicated procedures or higher requirements for investors. Hence, with the development of political stability the FDI inflows from developed economies may rise, but FDI inflows from developing ones may dwindle.

\begin{tabular}{|c|c|c|c|c|c|}
\hline & Corruption & $\begin{array}{l}\text { Government } \\
\text { Management }\end{array}$ & Inclusion & External Policy & Political Risk \\
\hline \multirow{2}{*}{$\begin{array}{l}\text { Logarithm of } \\
\text { GRP importer }\end{array}$} & $0.7985^{* * *}$ & 0.8039 *** & $0.7900 * * *$ & $0.8131 * * *$ & $0.8010^{* * *}$ \\
\hline & $(10.52)$ & $(10.92)$ & $(9.92)$ & $(11.15)$ & $(10.15)$ \\
\hline \multirow{2}{*}{$\begin{array}{l}\text { Logarithm of } \\
\text { GRP exporter }\end{array}$} & $0.3957 * * *$ & $0.3872 * * *$ & $0.3927 * * *$ & $0.3971 * * *$ & $0.3937 * * *$ \\
\hline & $(8.10)$ & $(7.90)$ & (7.87) & $(8.11)$ & (8.03) \\
\hline \multirow{2}{*}{$\begin{array}{l}\text { Logarithm of } \\
\text { distance }\end{array}$} & $-1.2321 * * *$ & $-1.2405 * * *$ & $-1.2364 * * *$ & $-1.2442 * * *$ & $-1.2342 * * *$ \\
\hline & $(-16.49)$ & $(-16.25)$ & $(-16.77)$ & $(-17.43)$ & $(-16.83)$ \\
\hline \multirow{2}{*}{ Inflation } & -0.0028 & -0.0020 & -0.0042 & -0.0039 & -0.0027 \\
\hline & $(-0.88)$ & $(-0.72)$ & $(-1.35)$ & $(-1.17)$ & $(-0.90)$ \\
\hline \multirow{2}{*}{$\begin{array}{l}\text { Logarithm of } \\
\text { exchange rate }\end{array}$} & $-0.0858 * * *$ & $-0.0837 * * *$ & $-0.0792 * * *$ & $-0.0837 * * *$ & $-0.0850 * * *$ \\
\hline & $(-3.75)$ & $(-3.69)$ & $(-3.18)$ & $(-3.51)$ & $(-3.46)$ \\
\hline \multirow{2}{*}{ Openness } & -0.0176 & -0.0093 & -0.0207 & $\begin{array}{l}-0.0278 \\
\end{array}$ & -0.0240 \\
\hline & $(-0.38)$ & $(-0.20)$ & $(-0.45)$ & $(-0.62)$ & $(-0.52)$ \\
\hline \multirow{2}{*}{ Political Indicator } & -0.1335 & $-0.3118^{* *}$ & 0.0699 & 0.0854 & -0.0020 \\
\hline & $(-0.88)$ & $(-2.05)$ & $(0.86)$ & $(1.03)$ & $(-0.15)$ \\
\hline \multirow{2}{*}{ Constant } & 0.5022 & 0.0113 & 0.0611 & -0.5611 & 0.3550 \\
\hline & $(0.43)$ & $(1.25)$ & $(0.05)$ & $(-0.51)$ & $(0.29)$ \\
\hline $\mathrm{r} 2$ & 0.0685 & 0.0715 & 0.0672 & 0.0665 & 0.0684 \\
\hline $\mathrm{N}$ & 34619 & 34619 & 34619 & 34619 & 34619 \\
\hline
\end{tabular}

Note: Robust standard errors are in the parenthesis. $* * *$ indicates $1 \%$ significance level, $* *$ indicates $5 \%$ significance level and $*$ indicates $10 \%$ significance level.

\section{Source: Authors}

\section{Conclusion}

As a synopsis of the research findings, the first hypothesis stating that the indicators or markers of political stability are directly proportionate to foreign direct investment, is verified. In conformity with the groups of countries, political stability is apparently more significant for developed countries, especially if such a country is an investor. Developing economies prefer to invest in developed countries owing to a better control on corruption, higher indicators of inclusion, better investment profiles and efficient external policies. After proper analysis of the research results, it can be concluded that if developing economies seek an increase in foreign direct investment from developed economies, then it is imperative that they would need to enhance political environment and provide favorable conditions for the investor countries. However, political institutions seem to be useless for FDI inflows between developing countries, therefore, this conveys that other factors might be of greater importance for this group of countries instead of political institutions. This suggestion can be further researched and experimented upon and could improve the results for this group of countries. The second hypothesis remains established all the same. Different groups of countries tend to have different sets of markers of political stability and different effects altogether on FDI inflows. As per evaluations, the impact of greater political stability on the increase in FDI will be the most noticeable in developing countries, as and when a developed country invests. The econometric method employed in this research provides robust estimations. Nevertheless, it is also possible to apply instrumental methods for future studies. Furthermore, only proxy variables were used in this research. These variables are deemed to be capable of describing the institutional environment in the countries better, though they still have their limitations. The authors plan are planning to deal with this issue by 
widening the database and by adding quantitative indicators and dummy-variables, which can refine the empirical research results.

\section{Acknowledgements}

This research was supported by the grant of the Russian Science Foundation No. 19-18-00262 "Empirical modelling of balanced technological and socioeconomic development in the Russian regions".

\section{References}

Bitar, Nicholas \& Hamadeh, Mohamad \& Khoueiri, Roy. (2019). Impact of Political Instability on Foreign Direct Investment in Lebanon. Asian Social Science. 16.41.10.5539/ass.v16n1p41.

Benassy-Quere, A., Couper, M., Mayer, T. (2007). Institutional Determinants of Foreign Direct Investment. The World Economy, 30 (5), 764-782. https://dx.doi.org/10.1111/j.1467-9701.2007.01022.x

Bevan, A., Estrin, S., Meyer, K. (2004) Foreign investment location and institutional development in transition economies. International Business Review, 13 (1), 43-64. https://dx.doi.org/10.1016/j.ibusrev.2003.05.005

Brunetti, A., Weder, B. (1998). Investment and Institutional Uncertainty: A comparative Study of Uncertainty Measures. Review of World Economics, 134 (3), 513-533. https://dx.doi.org/10.1007/BF02707928

Daude, Ch., Stein, E. (2007, February). The Quality of Institutions and Foreign Direct Investment. Economics and Politics, 19 (3), 317-344. https://dx.doi.org/10.1111/j.1468-0343.2007.00318.x

Fry, Maxwell J., Classens, Stijn, Burridge, Peter \& Blanchet, M. C. (1995). Foreign direct investment, other capital flows, and current account deficits: What causes what? World Bank Policy Research Paper 1527, World Bank, Washington, D.C.

Groznykh R., Mariev O. (2019). Impact of Institutional Factors on Foreign Direct Investment Inflows: Cross-Country Analysis. Journal of Economic Theory, 16 (2), 305-311. https://dx.doi.org/10.31063/2073-6517/2019.16-2.11

Knack, S., Keefer, P. (1995). Institutions and Economic Performance: Cross-Country Tests Using Alternative Institutional Measures. Economics and Politics, 7(3), 207-227. https://dx.doi.org/10.1111/j.1468-0343.1995.tb00111.x

Mádr M., Kouba L. (2015). Does the Political Environment Affect Inflows of Foreign Direct Investment? Evidence from Emerging Markets. Acta Universitatis Agriculturae et Silviculturae Mendelianae Brunensis, 63(6), 2017-2026.

Mariev O., Drapkin I., Chukavina K. (2016) Is Russia successful in attracting foreign direct investment? Evidence based on gravity model estimation. Review of Economic Perspectives. 16(3), 245-267. https://dx.doi.org/10.1515/revecp-2016-0015

Mayer, T., Zignago, S. (2011, December). Notes on CEPII's distances measures: The GeoDist database. CEPII Working Papers, 2011-25. Retrieved from: http://www.cepii.fr/CEPII/en/publications/wp/abstract.asp?NoDoc=3877

Silva S., Tenreyro, S. (2006) The Log of Gravity. The Review of Economics and Statistics. 88(4), 641-658. https://dx.doi.org/10.1162/rest.88.4.641

Singh, Harinder, \& Jun, K. W. (1995). Some new evidence on determinants of foreign direct investment in developing countries. World Bank Policy Research Paper 1531, World Bank, Washington, D.C.

Tintin C. (2013) The determinants of foreign direct investment inflows in the Central and Eastern European Countries: The importance of institutions. Communist and Post-Communist Studies. 46, pp. 287-298.

https://dx.doi.org/10.1016/j.postcomstud.2013.03.006

The PRS Group (2018). International Country Risk Guide Methodology. Retrieved from: https://www.prsgroup.com/wpcontent/uploads/2012/11/icrgmethodology.pdf 